\title{
West Nile Virus: An Emerging Threat in Transplant Population
}

\author{
Anna Mrzljak, ${ }^{1,2}$ Petra Dinjar-Kujundzic, ${ }^{1}$ Marija Santini, ${ }^{2,3}$ Ljubo Barbic, ${ }^{4}$ Iva Kosuta, ${ }^{1}$ Vladimir Savic, ${ }^{5}$ \\ Irena Tabain, ${ }^{6}$ and Tatjana Vilibic-Cavlek ${ }^{2,6}$
}

\begin{abstract}
West Nile virus (WNV) has become one of the new challenges for transplant programs. In addition to transmission by mosquito bite, interhuman transmission is possible through blood products or organ transplantation. Majority of WNV infections present as asymptomatic or mild febrile illness, with less than $1 \%$ of infected developing neuroinvasive disease. Many studies report naturally acquired or donor-derived WNV infections in solid-organ transplant recipients, mainly kidney, but also liver, heart, lungs and pancreas. Given the much higher risk of neuroinvasive disease ( $40 \%$ and even higher) based on serologic and clinical studies and increased mortality in transplant population, WNV infection should be considered in all patients presented with fever and neurological symptoms after transplantation, especially during the arbovirus transmission season.
\end{abstract}

Keywords: West Nile virus, mosquito, immunology, neuroinvasive disease, encephalitis

$\mathbf{C}$ URRENTLY, West Nile VIRUS (WNV) is one of the most widely distributed emerging arboviruses. In the last decade, WNV infections are continuously reported in many parts of the world. In the United States, the annual number of disease cases varied from 712 to 5674 (Centers for Disease Control and Prevention; CDC 2019), while in Europe, the number of WNV disease cases ranged from 74 to 262 (European Centre for Disease Prevention and Control; ECDC 2019). In the 2018 transmission season, European Union Member States and neighboring countries have reported the highest number of cases so far with a total of 2083 human WNV disease cases and 181 deaths (ECDC 2019).

In nature, WNV is maintained in a bird-mosquito-bird cycle, while humans represent incidental or "dead-end" hosts. However, interhuman transmission is possible through blood products or organ transplantation (Centers for Disease Control and Prevention; CDC 2002).

Although majority of WNV infections are asymptomatic $(\sim 80 \%)$ or present as a mild self-limited febrile illness ( $20 \%)$, less than $1 \%$ of infected persons develop neuroinvasive disease (meningitis, encephalitis, and myelitis). Ad- vanced age, immunosuppression, and comorbidities, such as cancer, hypertension, diabetes, and cerebrovascular disease, are risk factors for neuroinvasive infection and long-term sequelae (O'Leary et al. 2004, Murray et al. 2006, VilibicCavlek et al. 2019). Mortality in patients with neuroinvasive disease may reach up to $10 \%$ (Sejvar 2016).

Transmission of WNV by organ transplantation was first reported in 2002 (CDC 2002, Iwamoto et al. 2003). Serologic and clinical studies estimate that the risk of neuroinvasive disease in transplant patients infected with WNV is $40 \%$ and even higher (Table 1) than in the general population $(1 \%)$ (Kumar et al. 2004a). In addition, WNV is associated with an increased mortality in the transplant population. In one case series of 11 transplant recipients, a mortality rate of $18 \%$ and a high incidence of neurological sequelae were reported, including mechanical ventilation dependence (KleinschmidtDeMasters et al. 2004). However, there are several reports of WNV neuroinvasive disease after solid-organ transplantation (SOT) with a complete recovery (Hardinger et al. 2003, Desalvo et al. 2004, Saquib et al. 2008) and asymptomatic WNV infections as well (Rabe et al. 2013, Winston et al. 2014).

\footnotetext{
${ }^{1}$ Department of Medicine, Merkur University Hospital, Zagreb, Croatia.

${ }^{2}$ School of Medicine, University of Zagreb, Zagreb, Croatia.

${ }^{3}$ Department of Neuroinfections and Intensive Care Medicine, University Hospital for Infectious Diseases "Dr Fran Mihaljevic", Zagreb, Croatia.

${ }^{4}$ Department of Microbiology and Infectious Diseases with Clinic, Faculty of Veterinary Medicine, University of Zagreb, Zagreb, Croatia.

5Poultry Center, Croatian Veterinary Institute, Zagreb, Croatia.

${ }^{6}$ Department of Virology, Croatian Institute of Public Health, Zagreb, Croatia.
} 


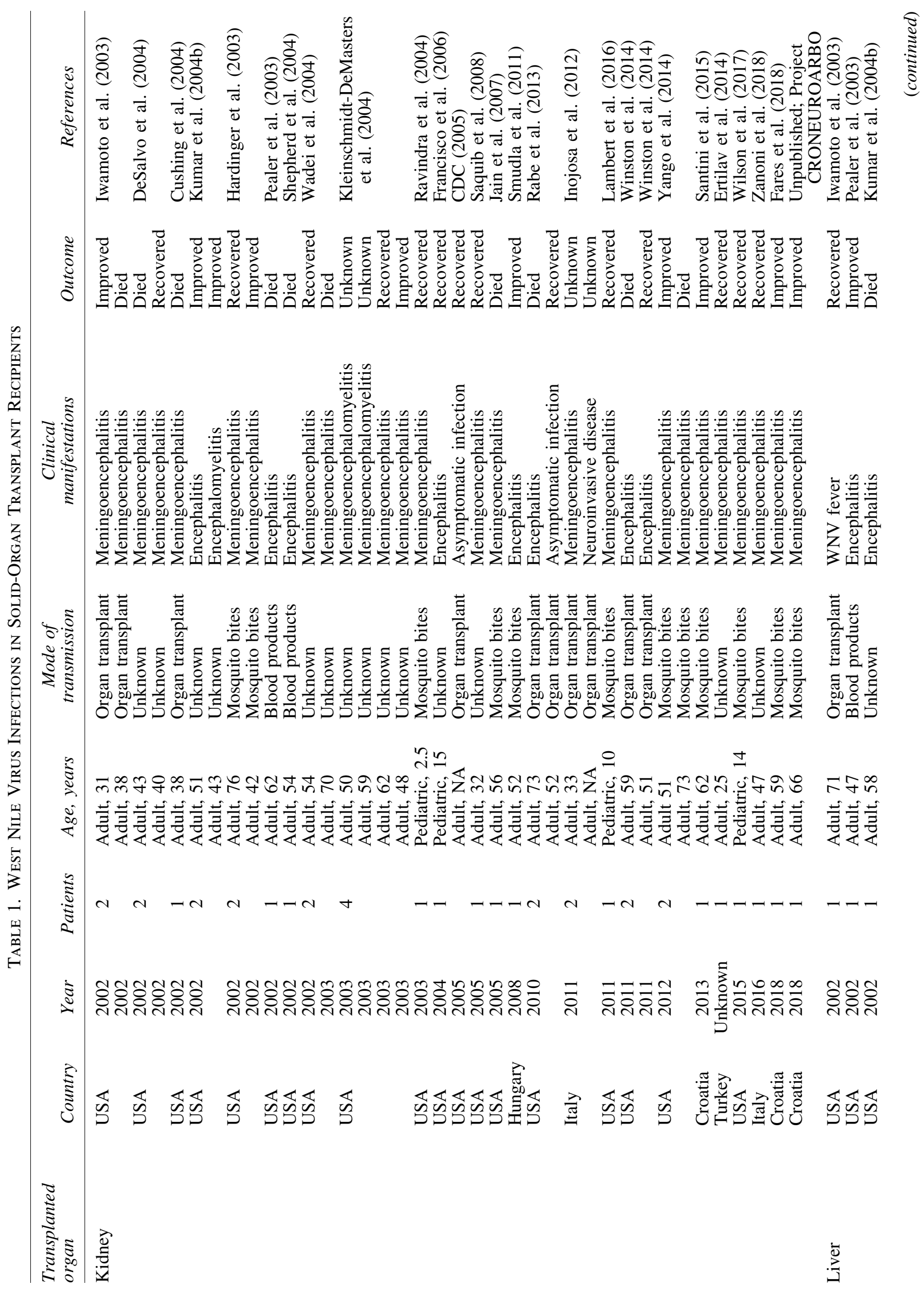




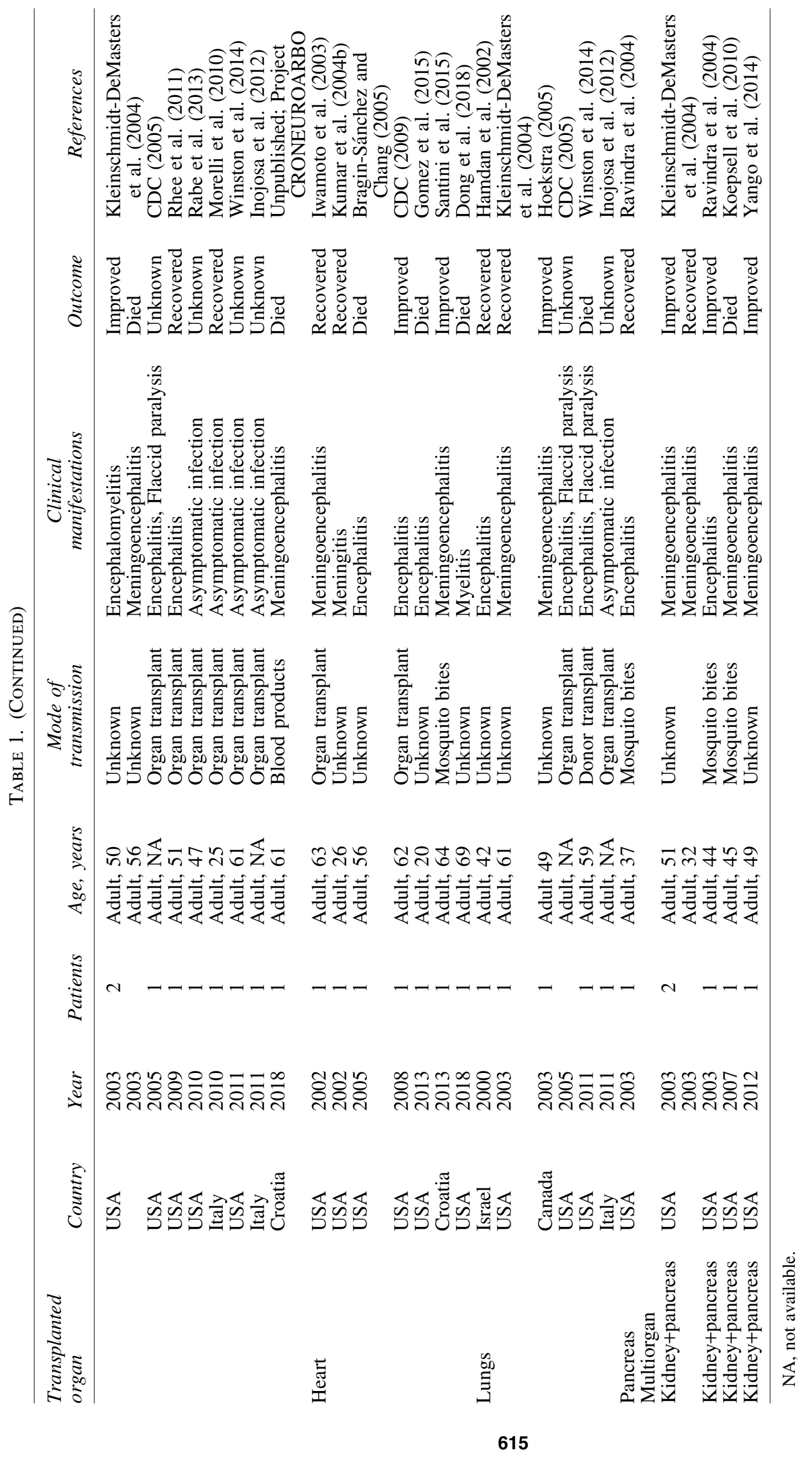


There are many studies reporting donor-derived or naturally acquired WNV infections in the adult SOT recipients, mainly kidney, but also liver, heart, lungs, and pancreas. However, data on WNV infections in the pediatric SOT population are very limited (Table 1). As in the general population, it seems that risk of fatal neuroinvasive disease in the pediatric transplant population is lower compared to adults. Four reports describing post-transplant WNV meningoencephalitis in pediatric patients aged from 2.5 to 15 years showed a complete recovery in all patients (Ravindra et al. 2004, Francisco et al. 2006, Lambert et al. 2016, Wilson et al. 2017).

Detection of $\operatorname{IgM}$ antibodies in cerebrospinal fluid (CSF) and/or serum using enzyme immunoassay is currently the most sensitive diagnostic test for WNV infection. Because WNV IgM may not be positive until up to 8 days following disease onset, specimens collected less than 8 days after the onset may be negative for $\operatorname{IgM}$, and testing should be repeated. In contrast, IgM antibodies may persist up to 500 days after primary WNV infection or even longer in some patients (Papa et al. 2011). Determination of IgG avidity may be helpful in these cases (Vilibic-Cavlek et al. 2018). Detection of WNV IgM in CSF strongly suggests acute infection, as IgM does not easily cross the blood-brain barrier. Due to high level of cross-reactivity between flaviviruses, the virus neutralization test is still the "gold standard" confirmatory testing for WNV infection (Di Gennaro et al. 2014). Other methods, including RT-PCR testing, can be helpful, but are significantly less sensitive than antibody tests and should be done in conjunction with serology. However, RT-PCR on serum, CSF, and urine samples may sometimes be the only method for WNV diagnosis in individuals who are unable to mount a detectable immune response such as transplant population (Koepsell et al. 2010).

There is no specific therapy against WNV available. Supportive treatment and reduction of immunosuppression are the first line of interventions in severe cases. Ribavirin, interferon alpha-2b, and immunoglobulins were considered in treating WNV disease with inconsistent results (Sejvar et al. 2003, Gea-Banacloche et al. 2004, Hart et al. 2014, CDC 2020). Potency of ribavirin and interferon alpha-2b was documented in vitro, although clinical efficacy was not established. Possible explanations for unfavorable outcomes could be related to drug and patients' characteristics such as: high drug concentrations, limited drug penetration into central nervous system (CNS), a consequential toxicity, along with delayed drug application, older age, female gender, and comorbidities (Chowers et al. 2001, Anderson et al. 2002, Hart et al. 2014). Administration of intravenous immunoglobulins (IVIG) with high titers of WNV antibodies in early stage of the disease could provide favorable results. Animal studies suggest the effect of passive antibody transfer after virus has reached the CNS, but efficacy declines with time indicating that administration of immunoglobulins should be as early as possible (Shimoni et al. 2001, BenNathan et al. 2003, 2009, Saquib et al. 2008, Makhoul et al. 2009, Morelli et al. 2010, Rhee et al. 2011). However, further clinical trials are needed to address the timing and route of IVIG administration, as well as their therapeutic efficacy.

In an attempt to improve transplant outcomes related to WNV disease, identification of infected organ and blood donors is necessary in WNV endemic areas during increased WNV activity (Winston et al. 2014, Anesi et al. 2019). Although current recommendations and screening practices of organ donors for WNV are not harmonized, WNV nucleic acid amplification testing is recommended (Anesi et al. 2019). Deferral of organ donors with known WNV infection or recent fever or unexplained neurologic symptoms should be considered (Winston et al. 2014, Anesi et al. 2019).

In the post-transplant period, WNV infection may be prevented by avoiding mosquito bites. Patients should be counseled to avoid outdoor activities in the period of the highest mosquito activity, to use long sleeves and long pants, and to apply repellents on exposed skin (Anesi et al. 2019).

Furthermore, effective WNV vaccines for horses but no licensed vaccine for humans exist. Several clinical trials were conducted with promising results (Ulbert 2019). Implementation of a vaccine for high-risk patients may be feasible, whereas mass vaccination is not cost effective (Amanna et al. 2014).

In conclusion, WNV has become one of the new challenges for transplant programs worldwide. In light of the WNV emergence, clinicians should be aware that transplant recipients could be exposed to WNV through multiple sources, including direct infection from the bite of mosquitoes, transfusion of blood products, and graft from an infected donor. Therefore, WNV infection should be considered in all patients presented with fever and neurological symptoms after transplantation, especially during the arbovirus transmission season.

\section{Author Disclosure Statement}

No potential conflicts of interest. No financial support.

\section{Funding Information}

This study was supported, in part, by the Croatian Science Foundation, project no. IP 2016-06-7456: Prevalence and molecular epidemiology of emerging and reemerging neuroinvasive arboviral infections in Croatia; CRONEUROARBO (to TVC).

\section{References}

Amanna IJ, Slifka MK. Current trends in West Nile virus vaccine development. Expert Rev Vaccines 2014; 13:589-608.

Anesi JA, Silveira FP; AST Infectious Diseases Community of Practice. Arenaviruses and West Nile Virus in solid organ transplant recipients: Guidelines from the American Society of Transplantation Infectious Diseases Community of Practice. Clin Transplant 2019; 33:e13576.

Anderson JF, Rahal JJ. Efficacy of interferon alpha-2b and ribavirin against West Nile virus in vitro. Emerg Infect Dis 2002; 8:107-108.

Ben-Nathan D, Lustig S, Tam G, Robinzon S, et al. Prophylactic and therapeutic efficacy of human intravenous immunoglobulin in treating West Nile virus infection in mice. J Infect Dis 2003; 188:5-12.

Ben-Nathan D, Gershoni-Yahalom O, Samina I, Khinich Y, et al. Using high titer West Nile intravenous immunoglobulin from selected Israeli donors for treatment of West Nile virus infection. BMC Infect Dis 2009; 17:18. 
Bragin-Sánchez D, Chang PP. West Nile virus encephalitis infection in a heart transplant recipient: A case report. J Hear Lung Transplant 2005; 24:621-623.

Centers for Disease Control and Prevention (CDC). Update: Investigations of West Nile virus infections in recipients of organ transplantation and blood transfusion -Michigan 2002. Morb Mortal Wkly Rep 2002; 51:879.

CDC. West Nile virus: Available at: www.cdc.gov/westnile/ statsmaps/cumMapsData.html Accessed: December 2019.

CDC. West Nile virus Treatment and Prevention,. Available at www.cdc.gov/westnile/healthcareproviders/healthCareProvidersTreatmentPrevention.html Accessed: January 2020.

CDC. West Nile virus infections in organ transplant recipients-New York and Pennsylvania, August-September, 2005. MMWR Morb Mortal Wkly Rep 2005; 54:10211023.

CDC. West Nile virus transmission via organ transplantation and blood transfusion - Louisiana, 2008. MMWR Morb Mortal Wkly Rep 2009; 58:1263-1267.

Chowers MY, Lang R, Nassar F, Ben-David D, et al. Clinical characteristics of the West Nile fever outbreak, Israel, 2000. Emerg Infect Dis 2001; 7:675-678.

Cushing MM, Brat DJ, Mosunjac MI, Hennigar RA, et al. Fatal West Nile Virus Encephalitis in a Renal Transplant Recipient. Am J Clin Pathol 2004; 121:26-31.

Desalvo D, Roy-Chaudhury P, Peddi R, Merchen T, et al. West Nile virus encephalitis in organ transplant recipients: Another high-risk group for meningoencephalitis and death? Transplantation 2004; 77:466-469.

Di Gennaro A, Lorusso A, Casaccia C, Conte A, et al. Serum Neutralization Assay Can Efficiently Replace Plaque Reduction Neutralization Test for Detection and Quantitation of West Nile Virus Antibodies in Human and Animal Serum Samples. Clin Vaccine Immunol 2014; 21:1460-1462.

Dong E, Morris K, Sodhi G, Chang D, et al. Neuroinvasive West Nile Virus Post-Heart Transplantation: A Case Report. Transplant Proc 2018; 50:4057-4061.

Ertilav M, Özkul A, Zeytinollu A, Şen S, et al. Meningoencephalitis caused by West Nile virus in a renal transplant recipient. Mikrobiyol Bul 2014; 48:674-682.

European Centre for Disease Prevention and Control (ECDC). West Nile fever. Available at: https://ecdc.europa.eu/en/westnile-fever. Accessed: December 2019.

Fares S, Bratić T, Santini M, Kurolt I, et al. Severe West Nile virus (WNV) infection in a patient with a kidney transplant. In: Abstract book. ZIMS 18th Zagreb International Medical Summit 2018, p39

Francisco A, Glaser C, Frykman E, Cole B, et al. 2004 California pediatric West Nile virus case series. Pediatr Infect Dis J 2006; 25:81-84.

Gea-Banacloche J, Johnson RT, Bagic A, Butman JA, et al. West Nile Virus: Pathogenesis and Therapeutic Options. Ann Intern Med 2004; 140:545-553.

Gomez AJ, Waggoner JJ, Itoh M, Hollander SA, et al. Fatal West Nile virus encephalitis in a heart transplant recipient. J Clin Microbiol 2015; 53:2749-2752.

Hamdan A, Green P, Mendelson E, Kramer MR, et al. Possible benefit of intravenous immunoglobulin therapy in a lung transplant recipient with West Nile virus encephalitis. Transpl Infect Dis 2002; 4:160-162.

Hardinger KL, Miller B, Storch GA, Desai NM, et al. West Nile virus-associated meningoencephalitis in two chronically immunosuppressed renal transplant recipients. Am J Transplant 2003; 3:1312-1315.
Hart J, Tillman G, Kraut MA, Chiang HS, et al. West Nile virus neuroinvasive disease: Neurological manifestations and prospective longitudinal outcomes. BMC Infect Dis 2014; 14:248.

Hoekstra C. West Nile virus: A challenge for transplant programs. Prog Transplant 2005; 15:397-400.

Inojosa WO, Scotton PG, Fuser R, Giobbia M, et al. West Nile virus transmission through organ transplantation in northeastern Italy: A case report and implications for preprocurement screening. Infection 2012; 40:557-562.

Iwamoto M, Jernigan D, Guasch A, Trepka M, et al. Transmission of West Nile virus from an organ donor to four transplant recipients. Engl J Med 2003; 348:2196-2203.

Jain N, Fisk D, Sotir M, Kehl KS. West Nile encephalitis, status epilepticus and West Nile pneumonia in a renal transplant patient. Transpl Int 2007; 20:800-803.

Kleinschmidt-DeMasters BK, Marder BA, Levi ME, Laird SP, et al. Naturally acquired West Nile virus encephalomyelitis in transplant recipients: Clinical, laboratory, diagnostic, and neuropathological features. Arch Neurol 2004; 61:12101220.

Koepsell SA, Freifeld AG, Sambol AR, McComb RD, et al. Seronegative naturally acquired West Nile virus encephalitis in a renal and pancreas transplant recipient. Transpl Infect Dis 2010; 12:459-464.

Kumar D, Drebot MA, Wong SJ, Lim G, et al. A seroprevalence study of West Nile virus infection in solid organ transplant recipients. Am J Transplant 2004a; 4:1883-1888.

Kumar D, Prasad GVR, Zaltzman J, Levy GA, et al. Community-acquired West Nile virus infection in solid-organ transplant recipients. Transplantation 2004b; 77:399-402.

Lambert SL, Aviles D, Vehaskari VM, Ashoor IF. Severe West Nile virus meningoencephalitis in a pediatric renal transplant recipient: Successful recovery and long-term neuropsychological outcome. Pediatr Transplant 2016; 20:836-839.

Makhoul B, Braun E, Herskovitz M, Ramadan R, et al. Hyperimmune gammaglobulin for the treatment of West Nile virus encephalitis. Isr Med Assoc J 2009; 11:151-153.

Morelli MC, Sambri V, Grazi GL, Gaibani P, et al. Absence of Neuroinvasive Disease in a Liver Transplant Recipient Who Acquired West Nile Virus (WNV) Infection from the Organ Donor and Who Received WNV Antibodies Prophylactically. Clin Infect Dis 2010; 51:e34-e37.

Murray KO, Baraniuk S, Resnick M, Arafat R, et al. Risk factors for encephalitis and death from West Nile virus infection. Epidemiol Infect 2006; 134:1325-1332.

O'Leary DR, Marfin AA, Montgomery SP, Kipp AM, et al. The Epidemic of West Nile Virus in the United States, 2002. Vector-Borne Zoonotic Dis 2004; 4:61-70.

Papa A, Danis K, Athanasiadou A, Delianidou M, et al. Persistence of West Nile virus immunoglobulin $\mathrm{M}$ antibodies, Greece. J Med Virol 2011; 83:1857-1860.

Pealer LN, Marfin AA, Petersen LR, Lanciotti RS, et al. Transmission of West Nile virus through blood transfusion in the United States in 2002. N Engl J Med 2003; 349:1236-1245.

Rabe IB, Schwartz BS, Farnon EC, Josephson SA, et al. Fatal transplant-associated west nile virus encephalitis and public health investigation - California, 2010. Transplantation 2013; 96:463-468.

Ravindra K, Freifeld A, Kalil A, Mercer D, et al. West Nile Virus-Associated Encephalitis in Recipients of Renal and Pancreas Transplants: Case Series and Literature Review. Clin Infect Dis 2004; 38:1257-1260.

Rhee C, Eaton EF, Concepcion W, Blackburn BG. West Nile virus encephalitis acquired via liver transplantation and clinical 
response to intravenous immunoglobulin: Case report and review of the literature. Transpl Infect Dis 2011; 13:312-317.

Saquib R, Randall H, Chandrakantan A, Spak CW, et al. West Nile Virus Encephalitis in a Renal Transplant Recipient: The Role of Intravenous Immunoglobulin. Am J Kidney Dis 2008; 52:e19-e21.

Santini M, Vilibic-Cavlek T, Barsic B, Pandak N, et al. Demographic, Clinical and Laboratory Characteristics of $\mathrm{Pa}$ tients with West Nile Neuroinvasive Disease in Croatia, 2012-2013. Copenhagen, Denmark: 25nd ECCMID, 2015: P0634.

Sejvar JJ, Haddad MB, Tierney BC, Campbell GL et al. Neurologic Manifestations and Outcome of West Nile Virus Infection. J Am Med Assoc 2003; 290:511-515.

Sejvar J. West Nile Virus Infection. Microbiol Spectr 2016 [Epub ahead of print]; DOI: 10.1128/microbiolspec.EI100021-2016.

Shepherd JC, Subramanian A, Montgomery RA, Samaniego MD, et al. West Nile Virus Encephalitis in a Kidney Transplant Recipient. Am J Transplant 2004; 4:830-833.

Shimoni Z, Niven MJ, Pitlick S, Bulvik S. Treatment of West Nile virus encephalitis with intravenous immunoglobulin. Emerg Infect Dis 2001; 7:759.

Smudla A, Gerlei I, Gergely L, Varga M, et al. West Nile virus encephalitis in kidney transplanted patient, first case in Hungary: Case report. Intervent Med Appl Sci 2011; 3: $80-83$.

Ulbert S. West Nile virus vaccines - current situation and future directions. Hum Vaccin Immunother 2019; 15:23372342.

Vilibic-Cavlek T, Kristofic B, Savic V, Kolaric B, et al. Diagnostic significance of immunoglobulin $G$ avidity in symptomatic and asymptomatic West Nile virus infection. Rev Soc Bras Med Trop 2018; 51:591-595.
Vilibic-Cavlek T, Savic V, Sabadi D, Peric L, et al. Prevalence and molecular epidemiology of West Nile and Usutu virus infections in Croatia in the 'One health' context, 2018. Transbound Emerg Dis 2019; 66:1946-1957.

Wadei H, Alangaden GJ, Sillix DH, El-Amm JM, et al. West Nile virus encephalitis: An emerging disease in renal transplant recipients. Clin Transplant 2004; 18:753-758.

Wilson MR, Zimmermann LL, Crawford ED, Sample HA, Soni PR, et al. Acute West Nile Virus meningoencephalitis diagnosed via metagenomic deep sequencing of cerebrospinal fluid in a renal transplant patient. Am J Transplant 2017; 17 : 803-808.

Winston DJ, Vikram HR, Rabe IB, Dhillon G, et al. Donorderived West Nile virus infection in solid organ transplant recipients. Transplantation 2014; 97:881-889.

Yango A, Fischbach B, Levy M, Chandrakantan A, et al. West nile virus infection in kidney and pancreas transplant recipients in the Dallas-Fort worth metroplex during the 2012 Texas epidemic. Transplantation 2014; 97:953-957.

Zanoni F, Alfieri C, Moroni G, Passerini P, et al. Delayed Diagnosis of West Nile virus infection in a kidney transplant patient due to inaccuracies in commonly available diagnostic tests. Exp Clin Transplant 2018 [Epub ahead of print]; DOI: 10.6002/ect.2018.0107.

Address correspondence to: Anna Mrzljak Department of Medicine Merkur University Hospital Zajceva 19 Zagreb 10000 Croatia

E-mail: anna.mrzljak@mef.hr 